\title{
On Lifelong Learning in China: Old Patterns and New Prospects
}

\author{
Yaroslav V. Sokolovsky* \\ Siberian Federal University \\ 79 Svobodny, Krasnoyarsk, 660041, Russia
}

Received 18.07.2015, received in revised form 21.08.2015, accepted 15.10.2015

The article sheds some light on recent findings devoted to lifelong learning and its role in modern China. The author attempted to analyze several significant publications of recent years, which were devoted to the role of education in China and to new advances in the field of LLL in general.

Keywords: lifelong learning, China, education, governance, management, competencies.

DOI: 10.17516/1997-1370-2015-8-11-2663-2668.

Research area: pedagogy, philology .

China has relied heavily upon its lifelong learning to promote desired changes in political ideology, socioeconomic relations, and human productive capabilities

(Wang, V.C.X. Parker, J.).

\section{Role of $\mathbf{L L L}$}

\section{in the Economic Development} of China

In China the government supports lifelong learning practice on the local, provincial and national levels. The initiatives in this sphere have "a strong focus on improving cooperation between cities and higher education institutions to enhance provision of continuing education for a broad range of potential learners" (Lifelong Learning in China Emphasizes Continuing Education and Vocational Skills). Ms Lu Xin, Vice-Minister of Education of China, reinforced that continuing education is a very important element of lifelong learning, which is crucial for reforming of education towards a more up-to-date system, while highlighting the need for effective pooling of resources from universities and municipalities to that end. She ended by reiterating that the demand for continuing education is evident and broadly shared, but concrete provision of learning opportunities must be strengthened, that responds creatively to the demand, with a focus on bridging initial vocational education and higher education (ibid.).

A well-known, yet remarkable fact is that China is the third largest country in terms of geographical area in the world after Russia and Canada. Simultaneously it has the largest population on earth. Wang, V.C.X. Parker, J.

(C) Siberian Federal University. All rights reserved

* Corresponding author E-mail address: sokol_rus@hotmail.com 
(2014) believe that to outsiders, China's huge population could be seen as a problem: just feeding the people is a heavy burden. However, the Chinese regard their huge population as a vital asset in overall economic development. And even today many Chinese quote their late chairman Mao by saying, "many hands make light work." Here we would like to quote Kaplan, Sobin and Andors (1979, 126), who stipulate that "China's mass labor mobilization campaigns obscure boundaries between those who are in and outside of the workforce. Students attend class, but they also work while going to school. Peasants farm, but can also be employed in rural and urban industries in slack seasons. Women still bear a major responsibility for housework, but millions take part in neighborhood service centers and small-scale industries".

It is highly important that for the Chinese people learning is something preconscious and conscious at the same time, which results from the transformation of their experience in different contexts and stages in life and integration into the system of their own skills and abilities. A noteworthy fact is that one of the Chinese famous mottoes on lifelong learning improvement was uniting theory with practice, which implies the direct interaction of educational institutions with productive labor. What is more Wang, V.C.X. Parker, J. (2014) insist that "it is lifelong learning that produces surplus value. Without surplus value, humans could not have progressed from the Stone Age to modern civilization". In this connection, we need to quote the words of R. Kagia Director, Education Human Development Network, World Bank:

"Lifelong learning is education for the knowledge economy. Within this lifelong learning framework, formal education structures-primary, secondary, higher, vocational, and so on-are less important than learning and meeting learners' needs. It is essential to integrate learning programs better and to align different elements of the system. Learners should be able to enter and leave the system at different points. The learning system needs to include a multitude of players, such as learners, families, employers, providers, and the state. Governance in the lifelong learning framework therefore involves more than just ministries of education and labor" (Lifelong Learning in the Global Knowledge Economy).

Wang, V.C.X. Parker, J. (2014) noticed that the famous Marxist slogan of the $20^{\text {th }}$ century in China was changed into "From each according to his ability, to each according to his work". They assert that this slogan was one of the reasons, which "to some extent boosted lifelong learning throughout China especially in post-Mao China". The scholars propose seven viewpoints that can perform the function of a theoretical framework in any social setting: (1) lifelong learning is continuous and leads to additional performance; (2) lifelong learning is productive and produces goods and services; (3) lifelong learning requires physical and mental exertion; (4) lifelong learning has socio-psychological aspects; (5) lifelong learning is performed on a regular or scheduled basis; (6) lifelong learning requires a degree of constraint; and (7) lifelong learning is performed for a personal purpose (intrinsic or extrinsic) (ibid., 78).

Speaking of the situation in the 21 century Wang, V.C.X. Parker, J. believe that both urban and rural employment situations have produced a new problem-surplus labor in the 21st century in China. According to the National Bureau of Statistics in 2002, urban unemployment rate was about $4-5 \%$ of the labor force. Since over $60 \%$ was classified as rural in the census in the year 2000 , the unemployment rate is certainly much higher than is shown by official data. Due to the fact that many of the low skill level jobs are filled by rural surplus labor, it is hard for the urban unemployed 
to find jobs. The scientists believe that since China is turning from a command economy to a market economy, nowadays governmental authorities no longer allocate labor. Twenty years ago in China, a college degree was a guarantee of a good job, yet today college students with just a bachelor's degree can hardly find a quality job in China.

Nowadays the government is trying to mobilize both rural and urban workforces to surpass countries such as Japan, Germany and the United States. As of 2006, China successfully surpassed France and the United Kingdom in terms of its GDP. Today, China has become the world's second largest economy. After 20 to 30 years of continual economic reform, the country's foreign currency reserves reached a record $\$ 1$ trillion in March, 2007, as its factories produced goods for markets all over the world, heightening the likelihood of fresh trade tensions with the US. The Chinese government formed a new agency to oversee the investment of these foreign currency reserves, representing a powerful new force in international finance. Despite the fact that economic policies and institutions have facilitated China's economic growth - which has taken place at such a pace that it has astonished the rest of the world - the efficient use of human resources has also played an important role. When we talk about human resources in China, we need to turn to the definition of the country's labor force, which is far from clear given its large population. In any study of China's economic accomplishments, the mass labor mobilization to improve the lifelong learning of its human resources is what first comes to mind. On the one hand, China has set a brilliant example for other developing countries in terms of properly feeding its huge population by mobilizing its mass labor force. On the other hand, China has revealed a number of problems by changing its lifelong learning. In this connection, Wang, V.C.X. Parker, J. discuss lifelong learning in relation to labor distribution, skills and training, and labor allocation (ibid.) They believe that before the $20^{\text {th }}$ century illiteracy was one of the main problems facing the new government of China. The situation has happily changed since those days. We may state that since 1984, 11 Chinese units have won prizes from UNESCO for their work in eliminating illiteracy. Because of these efforts, by the end of the previous century, China's illiteracy rate among young and middleaged people dropped to less than $5 \%$. It was a great achievement of the entire nation. We may compare this data to 1949 , when over $90 \%$ of the general population were illiterate, this changed in the 1960s and 1970s when China's leaders emphasized the significance of education. Despite the fact that a lot of time and energy were wasted in the political power struggle, young workers and students did master some rudimentary production skills. Indeed, the labor force in China has undergone certain transformations. Nowadays the government set up many special economic development zones along its coastal provinces where China's workers, engineers and scientists are able to work side in close connection with their foreign colleagues.

As the channels for learning have opened, individuals (almost) anywhere can define, design and achieve their learning goals without institutional or state mediation (V. Hannon).

\section{LLL Today:}

\section{Are We Facing a New Paradigm?}

Having discussed the general guidelines for the role of LLL in modern Chinese society we want to switch to a general question: are there new features of LLL that are especially topical today?

V. Hannon (2015) stipulates that a variety of philosophers of the past tried to understand the 
driving force of learning. The question of purpose of learning has been posed and answers proposed. Some of the answers given to the question gained the status of eternal verities. Moreover, the question has classically been framed in terms of "education": it means the purposive arrangement of experiences to promote learning. And mankind cannot help learning. We are wired for it, and, because of that, our evolutionary status has been continuously improving.

At the same time V. Hannon writes that the debates on learning have never taken place in conditions such as the human race currently faces. Afterwards V. Hannon enumerates them:

- Existential threat to continuing life on the planet within a few generations

- Resource depletion of fundamental resources - water and food - and their inequitable distribution in a globalised context

- High levels of destructive violence (again, posing potential existential threat) often accompanied by fundamentalism and intolerance, with the concomitant issues of immigration and dislocation

- Technologies of awesome power and transformational scope (including of the very stuff of evolution and human beings), which pose threats, but also hold the potential to solve some of the challenges we face - many of which are of our own making.

The scholar believes that never before was the very planet's future under threat. Nor had we developed technologies with which we ourselves will, in the foreseeable future, merge. Old stories about economic competitiveness or personal fulfillment are not so important today. V. Hannon believes (ibid.), that "today learning has to be about saving our species on this planet, and in conditions which do justice to our aspirations for good lives".
V. Hannon asserts that another dislocation with the past arises in the democratization of this question, because previous generations had it answered on their behalf by élites supported by experts. Popular industrial educational patterns reproduced stratified societies. However, today an education worth having is not just that defined by other people. The scholar insists that the collective task, perhaps, is to help to shape those individual learning goals in order to address the greater challenges and possibilities our society faces as a species and in our communities. So, given that learning's purpose is to secure our survival in conditions which are better than just tolerable, we need to consider the challenges our society is facing today.

Here we need to talk about competencies that are in demand for today. We agree with K. Steffens (2015), who stipulates that a variety of documents were published by international organizations (UNESCO, World Bank, European Commission) which enumerated $21^{\text {st }}$ century key competences. The field of learning theories has also experienced some positive changes. Findings from neuroscience have promoted a better understanding of what really happens in the brain when we learn something. Meanwhile, the fact that learning increasingly takes place in virtual communities led some scholars to propose "connectivism" as a learning theory for the digital age (K. Steffens, 2015). Similarly, other scientists suggested a theory of "generativism" (ibid.), which aims at describing collaborative learning with digital technologies and open educational resources. We suppose that these theories are fitted out for a better description and explanation of lifelong learning than classical learning theories.

We fully agree with K. Steffens (2015), who supposes that our society has become a 
knowledge society in which lifelong learning is becoming increasingly important. In this context, Massive Open Online Courses (MOOCs) have recently received a great deal of attention. These MOOCs have spread at a quick pace in the last few years, although it is far from clear to what extent they rely on principles from learning theories and really support learning. Here, we suppose, our society should stick to the principles, which were described by the Director-General of UNESCO, the chairman of the Commission, Edgar Faure, who stated that the work of the Commission was based on four assumptions. The first principle was related to the idea that there was an international community, which was united by common aspirations, and the second principle was the belief in democracy and in education as its foundation. The third principle was "that the aim of development is the complete fulfilment of man, in all the richness of his personality, the complexity of his forms of expression and his various commitments - as individual, member of a family and of a community, citizen and producer, inventor of techniques and creative dreamer". The last assumption was that "only an over-all, lifelong education can produce the kind of complete man, the need for whom is increasing with the continually more stringent constraints tearing the individual asunder" (Steffens, 2015).

\section{Conclusion}

To sum up, we would like to quote Li Jiange from the Research Center of the State Council, People's Republic of China, who believes that "China is at a stage of development where it is experiencing rapid economic structural change. Over the last 30 years, about half of rural laborers have transferred into nonagricultural sectors, and about half have moved to the cities. This unprecedented population shift has driven China's fast-paced economic growth. However, the ensuing rapid industrialization and increased demand for skilled laborers requires an effective education and training system to quickly enhance the skills level of rural laborers, enabling them to benefit from wage increases, improved welfare, and full employment" (Li Jiange, 2015).

Nowadays it is evident that on-the-job learning has become an important channel for China's more than 700 million workers to obtain new knowledge and acquire the necessary working skills, whereas the quick transformation of the economic structure has increased the level of structural unemployment, making training a prerequisite for the unemployed to find new vacant places. We agree with Li Jiange that in addition to formal education, this will require a diverse continuing education and training system, and deployment of modern information technology to expand training opportunities.

\section{References}

Han Min. The New Progress on Lifelong Education Policies in China. Available from: http:// asemlllhub.org/fileadmin/www.dpu.dk/ASEM/events/RN4/Han_Min_English.pdf (Accessed October 19, 2015)

Hannon, V. (2015). What is Learning For? European Journal of Education, 50(1). DOI: 10.1111/ ejed.12107.

Kaplan, F. M.; Sobin, J. M. \& Andors, S. Encyclopedia of china today. New York, NY: Harper \& Row, Publishers, 1979.

Li Jiange. Enhancing China's Competitiveness. Through Lifelong Learning. Available from: ttp:// web.worldbank.org/WBSITE/EXTERNAL/WBI/WBIPROGRAMS/KFDLP/0,,contentMDK:213875 
73 menuPK:1727232 pagePK:64156158 piPK:64152884 theSitePK:461198 isCURL:Y isCURL:Y, 00.html (Accessed: September 20th, 2015)

Lifelong Learning in China Emphasizes Continuing Education and Vocational Skills. Available from http://uil.unesco.org/home/news-target/lifelong-learning-in-china-emphasises-continuingeducation-and-vocational-skills/c945ac66814f379845db509759a7e6d9/ (accessed October 19, 2015)

Lifelong Learning in the Global Knowledge Economy: Challenges for Developing Countries. A World Bank Report. Washington D.C. Available from: http://siteresources.worldbank.org/INTLL/ Resources/Lifelong-Learning-in-the-Global-Knowledge-Economy/lifelonglearning_GKE.pdf (Accessed: September 20 ${ }^{\text {th }}, 2015$ )

Steffens, K. Competences, Learning Theories and MOOCs: Recent Developments in Lifelong Learning. European Journal of Education 50(1), 41-59. DOI: 10.1111/ejed.12102.

Tennyson, D. R., Ordóñez de Pablos P. Impact of Economic Crisis on Education and the NextGeneration Workforce. IGI Global, 1 edition, 2015, 384 p.

UNESCO Institutefor Lifelong Learning. Available from: http://uil.unesco.org/about-us/ (Accessed October $\left.1^{\text {st }}, 2015\right)$

Wang, V.C.X. Parker, J. Lifelong Learning in China. Available from: http://www.raco.cat/index. php/RIO/article/viewFile/280823/368496 (Accessed October 19th, 2015).

\section{К вопросу о непрерывном образовании в Китае: старые модели и новые перспективы}

Я.В. Соколовский Сибирский федеральный университет Россия, 660041, Красноярск, пр. Свободный, 79

В статье затронуты вопросы обучения на протяжении всей жизни и его роль в современном Китае. Автор попытался проанализировать несколько существенных публикаций последних лет, которые были посвящены роли образования в Китае, и новых достижений в области LLL в целом.

Ключевые слова: непрерывное образование, Китай, управление, компетенции.

Научная специальность: 13.00.00 - педагогические науки, 10.00.00- филологические науки. 